\title{
End-of-life management and recycling of PV modules
}

\author{
Vasilis M. Fthenakis* \\ Environmental \& Waste Technology Group, Department of Advanced Technology, Brookhaven National Laboratory, P.O. Box 5000, \\ Upton, NY 11973-5000, USA \\ Received 25 May 2000
}

\begin{abstract}
Photovoltaics (PV) technology is undergoing a transition to a new generation of efficient, low-cost products based on thin films of photoactive materials. PV technology has definite environmental advantages over competing electricity generation technologies, and the PV industry follows a pro-active life-cycle approach to prevent future environmental damage and to sustain these advantages. An issue with potential environmental implications is the decommissioning of solar cells at the end of their useful life; a viable answer is recycling them when they are no longer useful. This paper presents a feasibility study for recycling thin-film solar cells and manufacturing waste, based on the current collection/recycling infrastructure and on current and emerging recycling technologies. Technology already exists for recycling PV modules and costs associated with recycling are not excessive. Published by Elsevier Science Ltd.
\end{abstract}

Keywords: Photovoltaics; Recycling; Decommissioning; Environment; Waste

\section{Introduction}

Photovoltaic (PV) energy is a renewable, versatile technology that can be used for almost anything that requires electricity, from small, remote applications to large, central power stations. In the past $20 \mathrm{yr}$, research and development has advanced PV from a costly space technology to an affordable worldwide energy technology firmly planted on the ground (Ervin, 1997). A new generation of low-cost products based on thin films of photoactive materials (e.g., amorphous silicon, copper indium diselenide (CIS), cadmium telluride (CdTe), and film crystalline silicon) deposited on inexpensive substrates, increase the prospects of rapid commercialization. A market study by the Utility Photovoltaic Group estimated a potential domestic market for PV of $9000 \mathrm{MW}$ at a system price of $\$ 3 / \mathrm{W}$ (NREL, 1996). A large-scale market penetration by PV will give great environmental benefits. The operation of PV systems does not produce any noise, toxic-gas emissions, nor "greenhouse gases". PV energy not only can help meet the growing worldwide demand for electricity, but it can do so without incurring the high

\footnotetext{
* Corresponding author. Tel.: + 1-516-344-2830; fax: + 1-516-3444486.

E-mail address: vmf@bnl.gov (V.M. Fthenakis).
}

environmental costs of burning fossil fuels. Relative to burning coal, every gigawatt-hour of electricity generated by PV would prevent the emission of up to 10 ton of sulfur dioxide, 4 ton of nitrogen oxides, 0.7 ton of particulates (including $1 \mathrm{~kg}$ of $\mathrm{Cd}$ and $120 \mathrm{~kg}$ of As), and up to 1000 ton of carbon dioxide (NREL, 1990).

The PV industry has adopted a pro-active and longterm strategy to preserve the environmentally friendly nature of the industry. Manufacturing solar panels presents some health, safety and environmental (HSE) concerns which were the focus of numerous studies at Brookhaven National Laboratory, under the auspices of the US Department of Energy's National Photovoltaic Program (e.g., Fthenakis et al., 1984; Moskowitz and Fthenakis, 1991; Fthenakis and Moskowitz, 1995; Moskowitz et al., 1994). One issue is decommissioning of PV modules at the end of their use. Modules are expected to last about $30 \mathrm{yr}$, and, then will have to be decommissioned and disposed or re-used in some ways. There is a concern about disposing them in municipal landfills because they may contain small amounts of regulated materials (e.g., $\mathrm{Cd}, \mathrm{Pb}$ and $\mathrm{Se}$ ). Environmental regulations can determine the cost and complexity of dealing with end-of-life PV modules. If they were characterized as "hazardous" then special requirements for material handling, disposal, record keeping and reporting would escalate the cost of module decommissioning. Recycling 
PV systems at the end of their useful life adds to the environmental benefits and can further enhance market support. Also recycling answers public concerns about hazardous materials in PV modules which can create barriers to market penetration. The feasibility of collection and recycling of spent PV modules is explored in this paper.

\section{Current recycling infrastructure}

In $1995,25 \%$ of all collected trash in the United States was recycled, up from about $13 \%$ in 1988 . Recycling is based on market forces, involving thousands of firms and municipalities. However, even one of the most valuable recyclable products, aluminum cans, are currently recycled at a rate of only $65 \%$ because of collection difficulties. Recycling involves a complex matrix of operational and material-specific systems, which include collection, drop-off and buy-back centers, commercial recycling centers, and material recovery facilities. Recycling of solar panels is even more complicated, because of the decades-long intervals between installing and discarding modules, their low concentration of valuable materials, and their geographical dispersion. In the following, we discuss the experience from recycling similar products in other industries and then formulate a feasible recycling plan for solar cells.

\subsection{Recycling of electronic and telecommunication devices}

The electronics and telecommunications industries recycle a wide range of used and unused products through a plethora of collection and processing channels. Large companies (e.g., AT\&T) combine in-house collection with collection by "reverse logistics" companies who provide collection, consolidation, pre-processing and transport services. Used computers and telephones typically are collected, consolidated, and shipped to a service center. The used items are regarded as used products, not wastes, during these first steps in the recycling sequence, and, as such, no waste handling or processing permits and procedures are required. The service center does one of three things: (1) refurbishes the used equipment for resale, (2) disassembles the unit for spare parts, or (3) dismantles the unit to reclaim the materials. Refurbished units and spare parts remain "products", while units and/or pieces sent for reclamation are "waste". The economics of recycling electronics and telecommunications is driven by the value of the usable components salvaged from recycled units and by their precious metals content.

\subsection{Recycling of $\mathrm{NiCd}$ batteries}

The battery industry addresses the issue of recycling collectively. A consortium of NiCd battery manufac- turers, the Portable Rechargeable Battery Association (PRBA), funds and oversees a non-profit take-back program administered by the Rechargeable Battery Recycling Corporation (RBRC), that uses dedicated collection and recycling facilities. Participating commercial and institutional generators agree to return spent $\mathrm{NiCd}$ batteries to designated consolidation facilities. Participating retailers receive recycling kits; they set up collection boxes, and send full boxes to the International Metals Reclamation Company, Inc. (INMETCO). City and county municipal collection centers also gather batteries and send them to consolidation centers which, in turn, send them to INMETCO. INMETCO is an integrated stainless steel recycler; they recover nickel and iron from $\mathrm{NiCd}$ batteries and use them into the $\mathrm{Fe}-\mathrm{Ni}-\mathrm{Cr}$ alloy which they sell to the stainless steel industry, and also recover high-purity cadmium which is returned to the $\mathrm{NiCd}$ industry. Approximately $85 \%$ of the large industrial $\mathrm{NiCd}$ batteries and $10 \%$ of the small consumer $\mathrm{NiCd}$ batteries are presently recycled in the US; the latter is expected to increase to $70 \%$ by 2001 . Details about these and other recycling programs can be found elsewhere (Reaven et al., 1996; Fthenakis et al., 1996).

\subsection{Possibilities for collecting and recycling solar cells}

A feasible recycling program for solar panels will require careful attention to the experiences of comparable industries and to the economics of collection and materials. The basic viability of any recycling program often hinges on the geographic concentration of the goods and their proximity to appropriate recycling facilities, and on their content of valuable materials. PV are not at present very concentrated - neither by geography, nor by content. Present markets for PV are dominated by dispersed installations, such as off-grid power systems for industrial sites, and stand-alone residential applications. Collection, therefore, presents a challenge.

Also, the total amount, concentration, and value of reclaimable material are low. For example, indium, the most costly of the thin-film constituents which is used in CIS solar cells, accounts only for $2.5-5 \%$ of the total projected cost of a CIS module. The lack of significant quantities of any key material makes it unlikely that the recovery of materials from spent modules is economically warranted.

Reaven et al. (1996), outlined three generic paradigms (i.e., utilities, electronics, and batteries) for an institutional infrastructure to meet the challenges of collecting and, subsequently, recycling solar panels. In the utility paradigm, large end-users (e.g., electric utilities) would be the primary owners and servicers of large, or large numbers of, PV systems; hence, utilities logically would be primarily responsible for getting the end-of-life modules to the recyclers. PV module recycling would be integrated with other utility programs, such as conservation, 
off-grid service tariffs, and demand-side management. Recycling charges would be imbedded in the rates charged by the utility, in the same way costs of decommissioning of gas, oil and nuclear power plants are imbedded in these rates.

In the electronics model, recycling of solar panels would mimic that of electronics and telecommunications products. Manufacturers would be individually responsible for collecting, consolidating, and transporting obsolete modules to the recyclers; this would likely involve reverse-logistics companies, and recycling would be done by integrated dismantlers (i.e., not exclusive to solar panels) and materials recyclers. Recycling services might be paid for by the generator, the manufacturer, or an escrow fund set aside when the PV systems were originally purchased.

In the battery paradigm, manufacturers would be collectively responsible for collecting and transporting modules to recyclers, probably through the incorporation of a collectively supported PV-module recycling entity. Reverse retail channels and consolidation entities might be responsible for collection, consolidation, and transport, and the modules would be recycled by dedicated dismantlers, and materials recyclers. Goods collected through reverse retail channels could be sent directly to smelters under pre-paid shipping arrangements. Consolidation entities could collect goods from municipal recycling centers and large commercial and institutional generators. Recycling services might be paid for by industry dues to the collective recycling entity.

While these generic examples are useful in identifying elements of collection and recycling programs that might be workable for solar panels, none fits all the potential needs of the PV industry. For example, while electric utilities are active in PV and system owners have systematically dismantled and disposed of large PV systems, the utilities are not, at present, large consumers of PV products, and their future roles are unclear. With increased market competition and impending deregulation, US utilities have been leaving conservation and demand-side management that would have provided a natural synergy with PV-system stewardship.

The electronics example also does not fit the current reality of thin-film PV. For example, while the economics of electronics and telecommunications recycling are driven by salvaging parts, reclaiming precious metals and by liability concerns, it is unlikely that thin-film PV technology will have any of these in amounts sufficient to pay the associated costs of collecting, consolidating, transporting, and processing end-of-life PV. Thin-film solar panels are dominated by their glass content, whereas printed circuit boards, computers, and telephones are dominated by metals (some quite valuable), plastics, and fiberglass. Printed circuit boards have high concentration of toxic metals (e.g., $\mathrm{Pb}$ in soldering) and they will fail the EPA's toxicity characteristic leaching procedure
(TCLP), whereas environmentally designed solar modules will have small quantities of such metals and they will pass this test. These differences in materials content have an important impact on recycling approaches and economics. Also, unlike electronics, where there are disparities in the product requirements for different international markets and the products have brief lifecycles, solar cells are characterized by slower rates of improvement that generally do not make existing installed systems sufficiently obsolete to warrant pre-end-of-life decommissioning and resale. Consequently, the resale volume of PV modules is low. Further, unlike electronics where the salvage of components and manual disassembly into major reclaimable materials streams is typical, solar panels have few easily removed parts, except for the mounting frame. Conversely, it may be possible to economically refurbish in the field PV modules in ground-level installations, since the major failure mechanism will be the external wiring/power connection.

The NiCd batteries paradigm was developed largely in response to potential regulatory threats to their sale and recycling markets, as used NiCd batteries fail the TCLP test. Concerns have also arisen about the Cd content of CdTe PV cells, but there are differences in quantities and form of Cd compounds between the two. In 1986, the US NiCd industry used 1272 metric ton of $\mathrm{Cd}$, about 1000 times more than what a $10 \mathrm{MW} / \mathrm{yr}$ PV industry would use. A size $\mathrm{C} \mathrm{NiCd}$ battery contains about 20 times more cadmium per watt capacity than a CdTe module. Also, $\mathrm{CdTe}$ is less soluble than the cadmium oxide and cadmium hydroxide present in NiCd batteries. Preliminary studies on the toxicity of $\mathrm{CdTe}$ via the ingestion pathway, did not show the health effects attributed to cadmium dust or fumes (Harris, 1994); however, studies simulating the inhalation pathway showed such effects (Morgan et al., 1995; Fthenakis et al., 1999). Thin-film solar panels are unlikely to face potential regulatory burdens that warrant recycling to avoid costly and cumbersome disposal.

The above paradigms are useful in identifying elements of collecting programs that are likely to work for solar panels. In this context, we make three general observations:

(1) Paralleling the utility paradigm, collecting decommissioned solar panels is economically feasible for large, centralized installations, where the costs can be absorbed by the system's installer or capitalized by the system's owner.

(2) Paralleling the battery paradigm, reverse retail channels and periodic pick-up by reverse logistics companies may be the best strategy for collecting dispersed modules in small, remote installations and consumer applications. Recycling modules collected by municipal entities probably would be handled by the PV industry with an arms-length information role, providing guidance for municipalities, without getting directly involved with handling and recycling. 
(3) Multi-materials recyclers, such as those actively recycling electronics and telecommunications equipment, could be useful participants in recycling efforts for solar panels whether or not these panels provide the reclaim values of salvaging components and precious metals that normally support recycling. These multi-materials recyclers have a wide spectrum of process expertise that might accommodate PV module recycling in the future.

\section{Solar cell recycling feasibility}

A typical PV-module manufacturing facility will generate a significant amount of scrap at the start of its operation and, within six months to a year, will reach a steady-state level of production generating relatively little waste. For example, a current-specification thin-film PV manufacturing facility will have an annual production volume of approximately 2000 ton of solar panels, capable of generating $10 \mathrm{MW}$ electricity; from this tonnage only about $0.1 \%$ is semiconductor material, the rest being mainly glass. Assuming a $20 \%$ defects initially and $5 \%$ defects at steady production, the corresponding weights of total scrap are 200 ton the first six months and about $100 \mathrm{ton} / \mathrm{yr}$ for the rest of the facility operation (e.g., $10 \mathrm{yr}$ ). Then, 25-30 yr later, at the end of their useful life, 2000 ton of modules per year have to be decommissioned (Fig. 1). It is noted that this constitutes a very small fraction of the total anthropogenic waste stream, which in the US is currently in the giga-ton range.

In discussing PV recycling, one should distinguish between near-term and future needs and capabilities because of the long lapse between the start of manufacturing and decommissioning, and the corresponding differences in scale and technology. Near-term needs can be met by either centralized or de-centralized approaches, whereas future, large-scale needs would be more economically served by centralized strategies. Pyro-metallurgical processes are more suitable for centralized recycling, whereas hydro-metallurgical processes are more likely feasible for small de-centralized operations (Fig. 2).

\subsection{Centralized strategies}

Large smelters (e.g., Noranda, ASARCO), routinely recycle circuit boards, computer monitors, consumer electronics and telecommunication equipment to recover metals. Such facilities might incorporate the recycling of spent PV modules; today they recycle the relatively small amounts of scrap generated by PV manufacturers. The low concentration of metals in PV modules and scrap does not generate any significant recycling value, but their glass content has a certain value to smelter operators who buy silica for their fluxing operation. The glass credit, therefore, reduces the costs of treatment, which

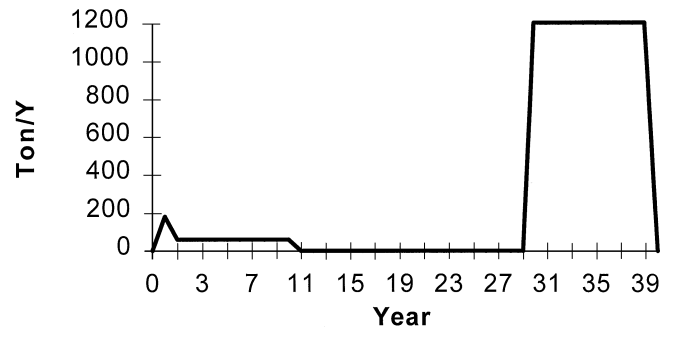

Fig. 1. Quantity of PV scrap and used modules from a $10 \mathrm{MW} / \mathrm{yr}$ manufacturing facility.

presently is $\$ 175-200 /$ ton $(\sim \$ 0.02 / \mathrm{W})$, for large deliveries (e.g., 20 ton containers). (In all the conversions from $\$ /$ ton to $\$ / \mathrm{W}$, we assumed thin-film cells encapsulated within two $2 \mathrm{~mm}$ glass sheets, $2 \mathrm{~kg}$ of $\mathrm{Al}$ frame per $\mathrm{m}^{2}$ of module, and a $10 \%$ electrical conversion efficiency.) Transportation cost is an additional \$220/ton (\$27-400/ton depending on location and quantity). Cadmium, tellurium, selenium, and contact metals (e.g., Ni) can be treated in copper smelters where the shredded material is processed through a liquid metal bath reactor, converters and anode furnaces. The glass content of the shred is used up in the fluxing operation of the smelter; the ethylene vinyl acetate (EVA) and plastic decompose at the high temperatures of the smelter (e.g., $1000-1400^{\circ} \mathrm{C}$ ) into carbon dioxide and monomeric vapors. In the furnaces, the anodes collect molten copper and the metals dissolved in it. These anodes are processed at the copper refinery, where metallurgical grade of tellurium and (if the supply is sufficient) of selenium are recovered electrolytically. Contact metals (e.g., Ni) accumulate in the solution and are removed in the purification and acid-recovery phases. Cadmium does not dissolve in molten copper but remains in the waste stream of the copper smelter. A zinc smelter can recover cadmium, but the process is sensitive to tellurium and other metals, and cannot accept CdTe scrap.

The projected cost of recycling CIS solar panels has been estimated for two cases (Fthenakis et al., 1996) (Table 1). First, a base case assuming that dispersed, low-concentration solar panels were collected for recycling via reverse retail or curbside municipal solid-waste channels. In this base case, a monetary incentive to the generator or primary collector of $\$ 1 /$ module might be necessary. The net of this scenario would be a recycling cost of about $\$ 0.08 / \mathrm{W}$. In the case of dispersed applications and direct shipping from the generator to the smelter, the projected cost is approximately $\$ 0.11 / \mathrm{W}$.

For comparison, the current cost of landfill disposal is about $\$ 0.01 / \mathrm{W}$ for large quantities of non-hazardous waste and $\$ 0.23 / \mathrm{W}$ for hazardous waste, excluding packaging and transportation costs which also depend on the type of the waste. Metals like cadmium and lead, although their concentration in a solar panel is 


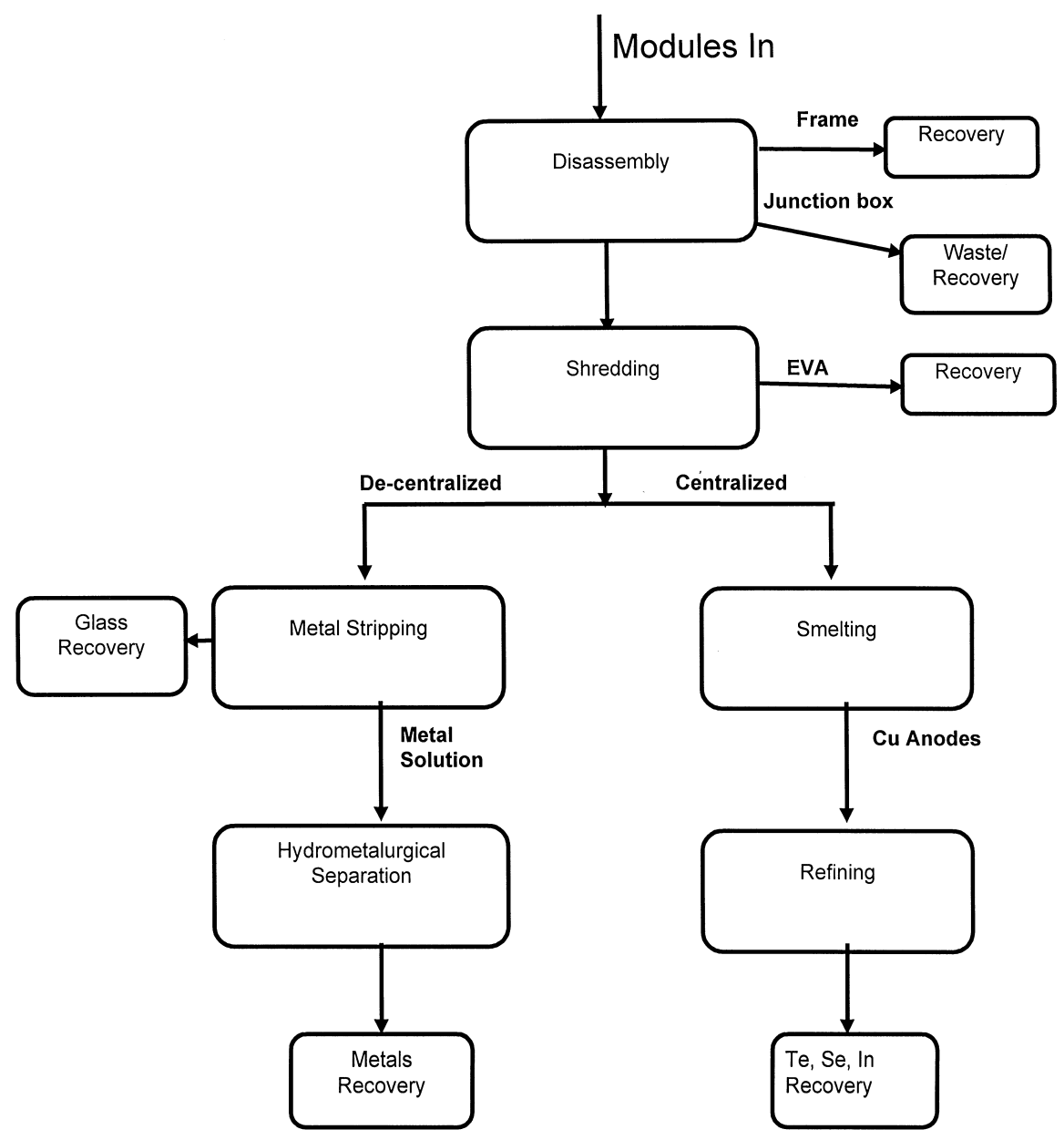

Fig. 2. PV scrap and module recycling options.

minuscule, may cause a hazardous waste classification, with all the associated cost implications. It would make sense to separate these metals from the glass (which is the bulk of a solar panel), if it can be done economically. The de-centralized recycling strategies discussed below follow this approach.

\subsection{De-centralized recycling strategies}

Separating the hazardous metals from glass and metal frame can accomplish a reduction of hazardous waste by three orders of magnitude. In small-scale operations, metals can be stripped of glass and plastic by physical (e.g., hammer mill, sand blasting, pyrolysis), or chemical methods. Chemical stripping using appropriate solvents (e.g., acids, oxidizers) is the most effective way to subsequently recover the metal. The metal-containing liquid can be treated in one of the following ways:

(a) By the traditional method of precipitating metals as hydroxides, collecting them as (hazardous) sludge, and disposing of it at a hazardous waste site or sending it to a smelting plant.

(b) By methods for concentrating metals in solution and recycling the solution within the plant by processes such as ion exchange, reverse osmosis, dialysis, and solvent extraction.

(c) By electrochemical methods for recovering metals directly (e.g., electrodeposition).

The most common method is hydroxide precipitation, since most metals can be precipitated at alkaline $\mathrm{pH}$. However, the process must be optimized for complete and selective precipitation. Amongst the solution-concentration techniques, ion exchange is widely practiced and can be very effective, but is more expensive than precipitation. Electrodeposition is occasionally practiced for cadmium. Both chemical precipitation and electrodeposition techniques are potentially adequate for separating cadmium/tellurium and copper/indium/ selenium but must be optimized to be fully effective. Recent research efforts, sponsored by the DOE Small 
Table 1

CIS PV recycling economics ${ }^{\mathrm{a}}$

\begin{tabular}{|c|c|}
\hline \multicolumn{2}{|c|}{ Base case recycling via reverse retail and/or curbside $M S W$} \\
\hline$-2.5 \phi / \mathrm{W}$ & $\begin{array}{l}\text { Incentive to generator and/or primary collector; } \\
\$ 1 / \text { module }\end{array}$ \\
\hline$+0.3 \phi / \Gamma$ & $\begin{array}{l}\text { Frame removal }(-1.2 \phi / \mathrm{W} \text { at } 3 \mathrm{~min}, \$ 10 / \mathrm{h}) \text { and salva } \\
(+1.5 \phi / \mathrm{W} \text { at } \$ 35 / \mathrm{lb})\end{array}$ \\
\hline$-2.3 \phi / \mathrm{W}$ & $\begin{array}{l}\text { consolidation and shipping by Reverse } \\
\text { s Co. at } 10 \notin / \mathrm{lb}\end{array}$ \\
\hline$-2.3 \phi / V$ & $1 . \quad 8 \quad . \quad 1000$ \\
\hline-1. & $\begin{array}{l}\text { ollective PV industry } \\
\text { ts }\end{array}$ \\
\hline $0 \notin / \mathrm{W}$ & NPV \\
\hline$-8 \phi / \mathrm{W}$ & Paid \\
\hline \multicolumn{2}{|c|}{ Generator-based recycling via direct transport to smelter } \\
\hline $0 \notin / \mathrm{W}$ & Incentive to generator and/or primary collector \\
\hline$-6.8 ф / \mathrm{W}$ & $\begin{array}{l}\text { Direct transport to smelter of framed modules in } \mathrm{sm} \\
\text { quantities; } 25 \notin / \mathrm{lb}\end{array}$ \\
\hline$-4.6 \phi / V$ & $\begin{array}{l}\text { Pre-processing and smelting of laminates in small } \\
\text { quantities at } \$ 400 / \text { ton }\end{array}$ \\
\hline$-11 \phi / \mathrm{I}$ & Paid by generator \\
\hline
\end{tabular}

${ }^{a}$ Estimated costs are 1998 US \$

Business Administration (SBIR) program, aimed at such optimization; the two firms involved are Solar Cells Inc. (currently First Solar Inc.) of Toledo, Ohio and Drinkard Metalox of Charlotte, North Carolina.

Solar Cells Inc. (SSI) developed an operation for recycling CdTe modules, which starts with disassembly of a module and recovery of lead wires (Fig. 3). Then, the module is crushed in a hammer mill. The module's parts (e.g., mounts, coated glass and most of the EVA) are separated during different times of the milling process. The crushed glass is stripped of metals in successive steps of chemical dissolution, mechanical separation, and precipitation or electrodeposition. At the end, the mounts, glass, and EVA are completely recovered. The recovery of tellurium is $80 \%$ or better, and it can be sold as commercial grade $(99.7 \%$ Te). The remaining metals (e.g., $\mathrm{Cd}, \mathrm{Te}, \mathrm{Sn}, \mathrm{Ni}, \mathrm{Al}, \mathrm{Cu}$ ) are contained in a Cd-rich sludge which is currently sent to INMETCO where $\mathrm{Cd}$ is recovered and eventually used as feedstock for $\mathrm{NiCd}$ batteries. The estimated total cost for this operation is approximately $4-5 \notin / \mathrm{W}$, excluding transportation (Sasala et al., 1996; Bohland et al., 1998).

Drinkard Metalox Inc. (DMI) developed operations for recycling CdTe and CIS modules. Their operations include chemical stripping of the metals and EVA, skimming off the EVA from solution, and successive steps of electrodeposition, precipitation, and evaporation to separate and recover the metals. DMI reports recovery of $95 \%$ or better of $\mathrm{Te}$ and $96 \%$ or better of $\mathrm{Pb}$ from CdTe modules. Chemical stripping leaves the $\mathrm{SnO}_{2}$-conducting layer intact on the glass substrate, potentially allowing the re-use of the substrates for PV deposition. They project a processing cost of $9 \notin / \mathrm{W}$ or less (Goozner et al., 1998).
SSI also reported a method to delaminate $x$-Si PV modules and recover crystalline $\mathrm{Si}$ wafers or functioning Si solar cells (Bohland et al., 1998). Their method starts by gently heating and manually peeling off the backsheet. Then inert atmosphere pyrolysis at about $500^{\circ} \mathrm{C}$ vaporizes the EVA lamination layer. SSI recovered functioning cells from solar coupons, with slightly lower electrical efficiency than the original ones. Si-cell recovery was estimated to cost about $13 \phi / \mathrm{W}$, for an operational scale of 150,000 $x$-Si cells per year. For comparison, a new $x$-Si cell costs at least $\$ 1.50 / \mathrm{W}$ to produce today (Bohland et al., 1998).

Pilkington Solar International (PSI) also used pyrolysis to recover $x$-Si wafers from full modules (Wambach, 1998). They worked with 706 full-size modules and they reported recovery of $60 \%$ of the wafers being processed. These wafers were reprocessed into cells, which had slightly better efficiency than the original ones. PSI did not attempt to recover functioning $\mathrm{Si}$ cells, and did not report costs for their process.

\section{Policy implications}

This section presents some thoughts on the expected impact of environmental policies and regulations on the cost of recycling; it is not meant to be a complete discussion on the subject. As policies and regulations constantly change such implications are far from certain.

In the previous section, we estimated a total cost of collection and recycling in the range of $\$ 0.08-0.11 / \mathrm{W}$. Such recycling costs will not be a market barrier at today's system prices, but they will be significant in a large-scale production when costs fall below $\$ 2-3 / \mathrm{W}$. It is noted that recycling costs are likely to decrease as the recycling technologies mature, whereas the landfill disposal costs are constantly increasing. Another consideration is avoiding future potential environmental liability for disposal. In the US, the generator of waste is liable for the cost of any site remediation that might be needed in the future, even if waste has been disposed according to current practices and regulations. The cost of this potential liability is difficult to be quantified; one approach is to assign to it a value equal to today's cost of hazardous waste disposal, which in the US is an average of $\$ 800 /$ ton. This corresponds to $\$ 0.09-0.10 / \mathrm{W}$ for today's thin-film solar cells, which covers the entire cost of collection and recycling. Under this assumption of avoided future liability, the cost of recycling is zero.

In rough terms the cost of collection and disposal or recycling is proportional to the weight of the recycled materials. Making the modules easy to disassembly, and separating the regulated materials (e.g., $\mathrm{Cd}, \mathrm{Pb}, \mathrm{Se}, \mathrm{Ni}$, $\mathrm{Cu}, \mathrm{Al}$ and $\mathrm{Ag}$ ) from the glass is the surest way to minimize the cost of recycling. On-site separation can accomplish it. 


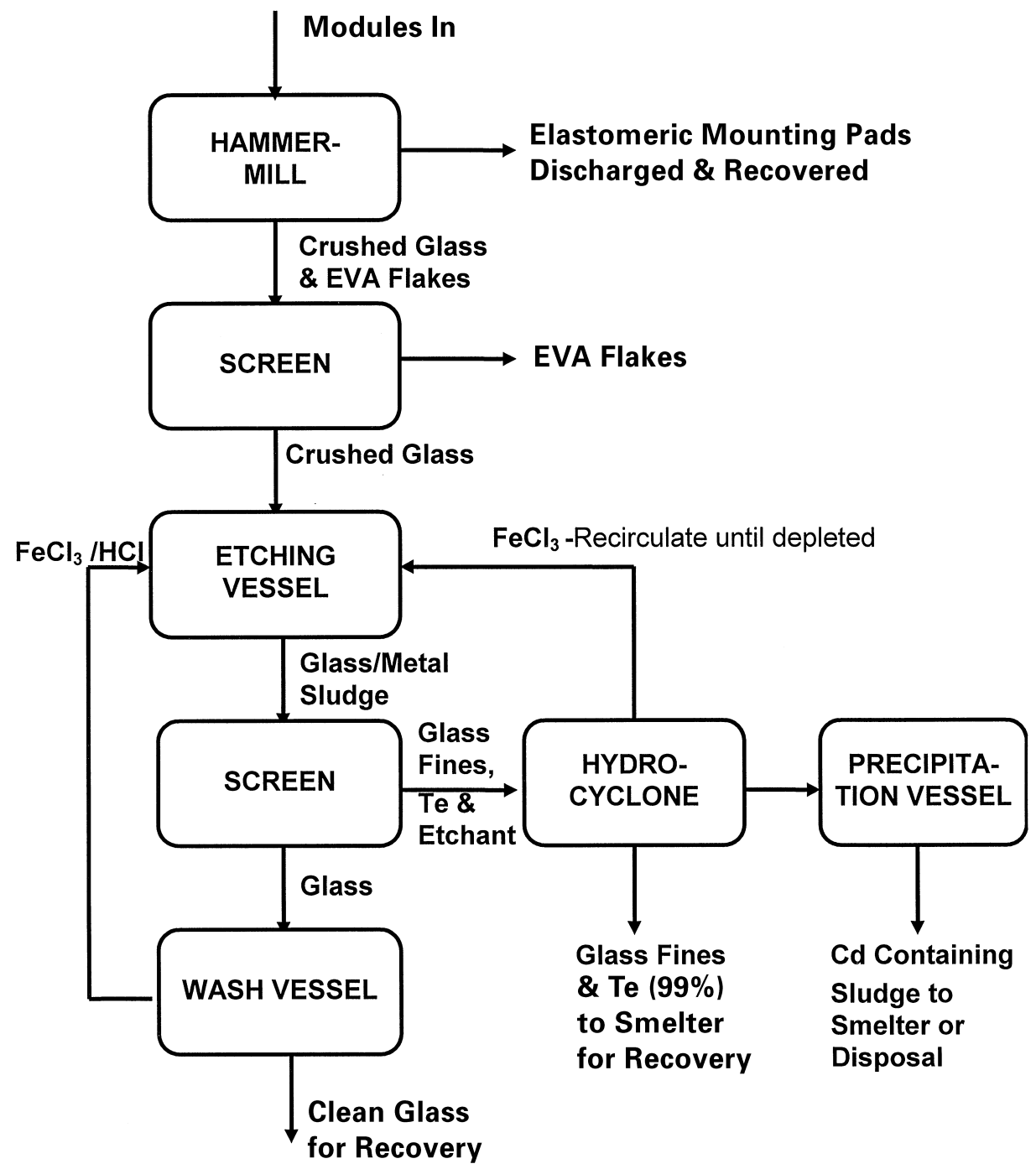

Fig. 3. Flowchart of a de-centralized PV recycling facility (First Solar, Inc.).

The events in the electronics industry can guide us regarding what to expect in the PV. A few years ago in the US, waste management regulations were complicating recycling. The situation has changed and material destined for recycling receives favorable treatment, being excepted from regulations during the collection, transfer, storage and processing stages. Several States have started programs in support of recycling electronic equipment; discarded electronics are described as "resource" instead of "waste" and the States assist in building up recycling infrastructure and market (EPR2, 1999)

Electronics product takeback legislation has been proposed in a number of European countries and the issue is discussed in several Asian countries (e.g., Japan, South Korea, Taiwan and Singapore). In Germany, a wellthought $\mathrm{Ni} / \mathrm{Cd}$ battery recycling program eased consumer concerns to the use of Cd. Similarly, the manufacturers of CdTe cells may win over the public support by implementing a full-cycle "cradle to grave" product stewardship program before they embark in a large-scale production.

Currently, economic incentives may be inadequate to move the PV industry into voluntary recycling. However, this may change in future, as more economic incentives may be given to developing clean technologies and reducing carbon dioxide emissions. This issue has not been investigated yet.

\section{Conclusions}

The PV industry follows a pro-active long-term environmental strategy to preserve the environmental 
friendliness of solar cells. In accordance to this strategy, options to recycle used solar cells and manufacturing waste are being investigated. The current study showed that such recycling is technologically and economically feasible, but not without careful forethought. A recycling program was outlined, based on current collection and recycling infrastructure and on emerging recycling technologies. Reclaiming metals from used solar panels in large centralized applications can be done in metal smelting/refining facilities which use the glass as a fluxing agent and recover most of the metals by incorporating them in their product streams. In dispersed operations, small quantities and high transportation costs make this option relatively expensive. Separating the PV materials from the glass reduces the amount of waste generated by three orders of magnitude. Research supported by the US DOE created effective, economical means of such separation that can be used in both small-scale (in-house) and large-scale recycling.

Environmental disposal and waste handling regulations, logistics and economics of product recycling and waste disposal affect the reasoning and practicality of recycling.

\section{Acknowledgements}

This work was supported by the Photovoltaic Energy Technology Division, Conservation and Renewable Energy, under Contract DE-AC02-76CH00016 with the US Department of Energy. Thanks are due to Chris Eberspacher of UNISUN, John Bohland of First Solar, Ken Zweibel of NREL, and Paul Moskowitz of BNL, for their contributions to this study, and to an anonymous reviewer for his/her significant comments.

\section{References}

Bohland, J., Dapkus, T., Kamm, K., Smigielski, K., 1998. Photovoltaics as hazardous materials; the recycling solution. In: Fthenakis et al. (Eds.), Presented at the BNL/NREL Workshop "PV and the Environment 1998", Keystone, CO, July 23-24.

EPR2, 1999. Electronic Product Recovery and Recycling Conference, State Initiatives panel discussion (panelists from Florida, Mass- achusetts, Minnesota, South Carolina and Wisconsin), March 23, Washington, DC.

Ervin, C., 1997. New photovoltaic center to serve as focal point. DOE This Month, January, p. 15.

Fthenakis, V.M., Morris, S.C., Moskowitz, P.D., Morgan, D.L., 1999. Toxicity of cadmium telluride, copper indium diselenide, and copper gallium diselenide. Progress in Photovoltaics: Research and Applications 7, 489-497.

Fthenakis, V.M., Eberspacher, C., Moskowitz, P.D., 1996. Recycling strategies to enhance the commercial viability of CIS photovoltaics. Progress in Photovoltaics: Research and Applications 4, 447-456.

Fthenakis, V.M., Moskowitz, P.D., 1995. Thin-film photovoltaic cells: health and environmental issues in their manufacture, use and disposal. Progress in Photovoltaics: Research and Applications 3, 295-306.

Fthenakis, V.M., Moskowitz, P.D., Lee, J.C., 1984. Manufacture of amorphous silicon and GaAs thin-film solar cells: an identification of potential health and safety hazards. Solar Cells 14, 43-58.

Goozner, R., Drinkard, W., Long, M., Byrd, C., 1998. In: Fthenakis et al. (Eds.), Presented at the BNL/NREL Workshop "PV and the Environment 1998", Keystone, CO, July 23-24.

Harris, M. W., 1994. The general and reproductive toxicity of the photovoltaic material cadmium telluride. Presented at the Society of Toxicology 1994 Annual Meeting, Dallas, TX, March 13-17.

Morgan, L.M., Shines, C.J., Jeter, S.P., Wilson, R.E., Elwell, P.E., Price, H.C., Moskowitz, P.D., 1995. Acute pulmonary toxicity of copper gallium diselenide, copper indium diselenide, and cadmium telluride intratracheally instilled into rats. Environmental Research 71, $16-24$.

Moskowitz, P.D., Fthenakis, V.M., 1991. Environmental, health and safety issues associated with the manufacture and use of II-VI photovoltaic devices. Solar Cells 30, 89-99.

Moskowitz, P.D., Fthenakis, V.M., Crandall, R.S., Nelson, B.P., 1994. Analyzing risks associated with hazardous production materials. Solid State Technology 37(7), 121-125.

NREL, 1996. Photovoltaics the power of choice, The National Photovoltaic Program Plan for 1996-2000. National Renewable Energy Laboratory, Golden, CO, January.

NREL, 1990. The potential of renewable energy, an interlaboratory Whiter paper. National Renewable Energy Laboratory, Golden, CO, SERI/TP-260-3674, March.

Reaven, S. J., Moskowitz, P. D., Fthenakis, V. M., 1996. Model institutional infrastructures for recycling of photovoltaic modules. BNL 62837, January.

Sasala, R.A., Bohland, J., Smigielski, K., 1996. Physical and chemical pathways for economic recycling of cadmium telluride thin-film photovoltaic modules. 25th IEEE Photovoltaic Specialists Conference. Institute of Electrical and Electronics Engineers, Inc., Piscataway, NJ, pp. 865-868.

Wambach, K., 1998. Recycling of PV modules. Presented at the Second World Photovoltaic Conference, July, Vienna. 